\title{
Carboxymethyl cellulose (CMC) whey product as protein source for growing pigs
}

\author{
MATTI NÄSI ${ }^{1)}$, MATTI IKONEN ${ }^{1)}$ and MATTI ANTILA ${ }^{2)}$ \\ 1) Department of Animal Husbandry and ${ }^{2)}$ Institute of Dairy Science, \\ University of Helsinki 00710 Helsinki 71
}

\begin{abstract}
A digestibility and balance trial was performed with three growing pigs to evaluate the nutritive value and protein utilization of a carboxymethyl cellulose (CMC) whey product used to replace $50 \%$ or $100 \%$ of the dried skim supplement in a barley-based diet. The effect of CMC whey on clinicalchemical blood parameters was also investigated. The CMC whey protein contained $39.6 \%$ crude protein and $36.0 \%$ true protein in DM. The proportion of $\mathrm{CMC}$ in the product was $18.3 \%$ of DM. CMC whey had high contents of lysine, cystine, methionine and threonine: $10.3,2.9,2.1$ and $5.6 \mathrm{~g} / 16 \mathrm{~g} \mathrm{~N}$, respectively. NFE digestibility was lower on the CMC whey diet than on the skim milk diet $(P<0.05)$. Faecal excretion of CMC averaged $59.0 \%$. Protein utilization was effective on the $\mathrm{CMC}$ whey diet: 69.9 $\%$ of absorbed $\mathrm{N}$ was retained. Judging from the blood analyses, the $\mathrm{CMC}$ whey product did not have any detrimental effect on the metabolism or health of the pigs. The CMC whey product is well suited as a protein supplement in pig feeding because of its high contents of essential amino acids.
\end{abstract}

\section{Introduction}

Whey is widely used as a feedstuff for pigs having a high energy content and being useful as a protein source in cereal diets. Moreover, due to the growth of the cheese industry, increasing amounts of whey are becoming available for feed purposes. Liquid whey deteriorates rapidly and high transport costs restrict its use, but drying of whey is becomig too expensive. Further, large whey supplements, over $30-40 \%$ of the energy intake for growing pigs, cause slow growth and digestional disturbances due to the high lactose and mineral content of whey (BARBER et al. 1978, MITCHELL 1978, ALAVIUHKOLA et al. 1979).

Whey proteins are digested well by pigs and owing to its suitable amino acid composition whey is a valuable protein supplement in cereal-based diets (DIGGS et al. 1965, HANRAHAN 1971). As the protein content of whey is low (13\% of DM) compared to its energy value, concentration of the protein content makes whey more suitable as a protein supplement and allows a decrease in the lactose intake.

Carboxymethyl cellulose (CMC) is as cellulose hydrocolloid (cellulose ether) produced from wood cellulose in reaction with sodium hydroxide and 
monochloroacetic acid. CMC produces complexes with proteins within the $\mathrm{pH}$ limits of 3.0 and 3.5 (HIDALGO and HANSEN 1971). It is used widely in the food industry as a coagulation and gelation additive (EC no. E 466).

The present metabolic study was undertaken to assess the nutritive value and utility of a CMC whey product as a protein supplement for growing pigs.

\section{Materials and methods}

A digestibility and nitrogen balance trial was carried out with three castarated Landrace pigs weighing $35-65 \mathrm{~kg}$. A total collection method was used and the experiment was desingned as a $3 \times 3$ Latin square, in which skim milk was replaced by the CMC whey product at two levels, $50 \%$ and $100 \%$ of the protein supplement. The transition period between diets was five days and the standardization and collection periods were both six days.

The basic feed was barley meal, milled with a 3-mm sieve and enriched with a mineral mixture (Seleeni-Terki) $40 \mathrm{~g} / \mathrm{d}$ and a vitamin mixture (Vitamiini-Nasu $15 \mathrm{~g} / \mathrm{d}$ ). The feed was supplemented with $15 \%$ skim milk powder, or $7.5 \%$ skim milk powder and $7.5 \%$ CMC whey product, or $15 \%$ $\mathrm{CMC}$ whey product (CMC whey ration calculated on a DM basis). The crude protein content of the diets averaged $15.8 \%$ of DM.

The CMC whey product was made at the Porlammi Co-operative Dairy from Emmental cheese whey. Whey, $5000 \mathrm{l}$ at $45-50^{\circ} \mathrm{C}$ was adjusted with $\mathrm{HCl}$ to $\mathrm{pH} 3.2$ and $7.5 \mathrm{~kg}$ carboxymethyl cellulose (CMC) was added in 3501 $50^{\circ} \mathrm{C}$ water, so that the $\mathrm{CMC}$ content was $1.5 \mathrm{~g} / \mathrm{l}$ whey. The whey was allowed to stand while the precipitate settled on the bottom of the tank. The supernatant above the CMC protein precipitate was pumped away. The $\mathrm{CMC}$ whey product ca. $500 \mathrm{l}$ was mixed and stored in a plastic container and kept deep forzen until used. After thawing it was fed to the pigs.

The daily rations in the different periods were $1.8,2.2$ and $2.4 \mathrm{~kg}$. They were given as liquid feed and the pigs were fed twice daily. Water was given after feeding and the remains of the feed were collected and subtracted from the feeds.

The faeces and urine were collected twice daily, and representative samples were stored frozen until analysed. The details of the procedure are described by NÄSI (1982).

Blood samples were taken from the anterior vena cava before feeding on the two days following each collection period. The treatment of the samples and the methods used were the same as described by NÄSI and TANHUANPÄÄ (1981).

The chemical analyses of the feeds and faeces were performed according to the official procedures. The CMC content was measured by the method of ZIEGEMAYER et al. (1951). Lactose was determined by the method of the IDF standard 28 (ANON. 1964). Amino acid was determined with a Technicon TSM autoanalyser. Minerals were measured with a Varian Techtron AA 1000 atomic absorption spectrophotometer. 


\section{Results and discussion}

The CMC whey product contained $39.6 \%$ crude protein $(\mathrm{CP})$ and 36.0 $\%$ true protein (TP). The CP content of whey or dried whey is $13 \%$ of DM and so by this CMC precipitation the protein content can be increased over threefold. Allowing the whey to stand for a longer time gives a wet whey product with a CP content of $50.7 \%$ of DM. The protein content of the product used here corresponds quite closely to the value of skim milk (Table 1). The lactose content of the CMC whey was $37.1 \%$ of DM, which is lower than that of skim milk powder. The ash content was about half that of skim milk (Table 1). The carboxymethyl cellulose content of the CMC whey averaged $18.3 \%$ of DM (CMC added at the rate of $1.5 \mathrm{~g} / \mathrm{kg}$ whey). Calculated per $\mathrm{kg} \mathrm{DM}$, the mineral contents of the $\mathrm{CMC}$ whey product were P 3.30 g, Ca 2.18 g, Mg 0.40 g, K 9.40 g, Na 40.6 g, Fe 12.7 mg, Cu 5.2 mg and $\mathrm{Zn} 2.2 \mathrm{mg}$. The mineral contents of $\mathrm{CMC}$ whey are much lower than those of dried skim milk or whey expect that of sodium, which is higher in CMC. Most of the values are only one fourth or fifth of those of skim or whey.

The essential amino acid composition of the CMC whey product was very suitable for supplementing a barley-based diet (Table 1). The high lysine

Table 1. Chemical composition of the experimental feeds.

\begin{tabular}{|c|c|c|c|}
\hline In dry matter & Barley & $\begin{array}{c}\text { Skim milk } \\
\text { powder }\end{array}$ & $\begin{array}{c}\text { CMC whey } \\
\text { product }\end{array}$ \\
\hline Dry matter, \% & 88.5 & 95.7 & 10.1 \\
\hline Ash, $\%$ & 2.8 & 8.2 & 4.4 \\
\hline Crude protein, $\%$ & 11.6 & 39.1 & 39.6 \\
\hline True protein, $\%$ & 9.7 & 35.5 & 36.0 \\
\hline Ether extract, \% & 3.5 & 0.1 & 0.6 \\
\hline Crude fibre, $\%$ & 5.7 & 0.0 & 0.0 \\
\hline NFE, $\%$ & 76.4 & 52.6 & 55.4 \\
\hline \multicolumn{4}{|c|}{ Amino acids $\mathrm{g} / 16 \mathrm{~g} \mathrm{~N}$} \\
\hline Alanine & 4.3 & 3.3 & 4.9 \\
\hline Arginine & 4.4 & 3.1 & 3.1 \\
\hline Aspartic acid & 6.3 & 8.3 & 11.8 \\
\hline Cystine & 2.3 & 0.8 & 2.9 \\
\hline Glutamic acid & 19.5 & 21.7 & 16.0 \\
\hline Glycine & 4.4 & 2.1 & 2.7 \\
\hline Histidine & 2.4 & 3.1 & 3.1 \\
\hline Isoleucine & 3.4 & 5.0 & 5.3 \\
\hline Leucine & 6.8 & 9.7 & 11.0 \\
\hline Lysine & 3.8 & 8.1 & 10.3 \\
\hline Methionine & 1.3 & 2.9 & 2.1 \\
\hline Phenylalanine & 4.9 & 4.9 & 4.3 \\
\hline Proline & 10.3 & 10.4 & 5.4 \\
\hline Serine & 4.4 & 5.3 & 5.3 \\
\hline Threonine & 3.7 & 4.7 & 5.6 \\
\hline Tyrosine & 2.3 & 4.5 & 3.7 \\
\hline Valine & 4.6 & 6.0 & 5.5 \\
\hline
\end{tabular}


Table 2. Digestibility coefficients of diets with and without the CMC whey product.

\begin{tabular}{|c|c|c|c|c|c|c|}
\hline & \multicolumn{4}{|c|}{ Protein supplement } & & \\
\hline & \multicolumn{2}{|c|}{$\begin{array}{l}\text { Skim milk powder } \\
100 \%\end{array}$} & \multicolumn{2}{|c|}{$\begin{array}{l}\text { Skim milk } 50 \% \\
\text { CMC whey } 50 \%\end{array}$} & \multicolumn{2}{|c|}{$\begin{array}{c}\text { CMC whey product } \\
100 \%\end{array}$} \\
\hline & $\overline{\mathbf{x}}$ & SD & $\overline{\mathbf{x}}$ & $\mathrm{SD}$ & $\overline{\mathbf{x}}$ & SD \\
\hline Dry matter & 84.0 & 0.9 & 82.6 & 0.7 & 82.1 & 1.7 \\
\hline Organic matter & 85.7 & 0.7 & 84.3 & 0.7 & 83.7 & 1.6 \\
\hline Ash & 55.8 & 2.8 & 52.6 & 1.8 & 53.0 & 2.6 \\
\hline Crude protein & 82.9 & 1.4 & 82.7 & 2.5 & 82.4 & 3.3 \\
\hline True protein & 89.2 & 1.7 & 88.0 & 1.2 & 88.3 & 2.0 \\
\hline Crude fat & 53.5 & 5.7 & 48.3 & 1.3 & 47.0 & 8.4 \\
\hline Crude fibre & 17.9 & 8.6 & 12.6 & 7.5 & 13.4 & 12.2 \\
\hline NFE & $92.1^{2}$ & 0.2 & $90.8^{\mathrm{ab}}$ & 0.2 & $90.1^{b}$ & 0.6 \\
\hline
\end{tabular}

Mean with different letters were significantly different $(P<0.05)$.

content, $10.3 \mathrm{~g} / 16 \mathrm{~g} \mathrm{~N}$, is especially promising and the contents of sulphurcontaining amino acids are also high, methionine $2.1 \mathrm{~g}$ and cystine $2.9 \mathrm{~g} / 16 \mathrm{~g}$ $\mathrm{N}$. Threonine amounted to $5.6 \mathrm{~g} / 16 \mathrm{~g} \mathrm{~N}$, which exceeded the value of skim milk.

The digestibilities of the diets containing CMC whey, skim milk or the combination of CMC whey and skim milk are presented in Table 2. The CMC whey diet had lower apparent digestibilities than the skim milksupplemented diet for dry matter, organic matter, crude fat and crude fibre, but the differences were not statistically significant $(\mathrm{P}>0.05)$. NFE digestibility was significantly lower in the CMC whey diet $(\mathrm{P}<0.05)$. Faecal excretion of $\mathrm{CMC}$ averaged $59.0 \pm 9.6 \%$ of intake (47-75\%). The CMC intakes averaged $54.9 \mathrm{~g} / \mathrm{d}$ at $100 \% \mathrm{CMC}$ whey protein supplementation and $27.4 \mathrm{~g} /$ $\mathrm{d}$ at $50 \% \mathrm{CMC}$ whey supplementation. $\mathrm{CMC}$ has been reported to be almost completely indigestible, exretion being $90 \%$ of intake in rats, $50 \%$ in rabbits and $90 \%$ in man (ZIEGELMAYER et al. 1951, ANON 1963). In pigs and rabbits the activity of microorganisms in the large intestine is high and it is possible that some bacterial strains can hydrolyse CMC. This, together with decomposition cellulose, will give lower recoveries of CMC in the faeces. The energy value of the CMC whey product is about $15 \%$ lower than that of skim milk, due to the indigestibility of CMC. The protein value is about the same, but can vary with the manufacturing procedure.

The apparent digestibility of the protein in the CMC whey product was on average $0.5 \%$ (CP) and $0.9 \%$ (TP) lower than the value for skim milk $(\mathrm{P}>0.05)$. The nitrogen balance was, however, higher on the $\mathrm{CMC}$ whey diet and the ratio of retained to absorbed nitrogen was fairly high, $69.9 \%$, exceeding the value for the skim milk diet by $3.8 \%$ ( $\mathrm{P}>0.05)$. The biological value was also $3.7 \%$ higher than for skim milk (Table 3 ). The pigs on the CMC whey diet had an average lysine intake of $18.8 \mathrm{~g} / \mathrm{d}$; the pigs on the skim milk diet $16.1 \mathrm{~g} / \mathrm{d}$. The corresponding values for threonine were 12.8 and $11.7 \mathrm{~g} / \mathrm{d}$. On barley-based diets supplementation of lysine and threonine is of great importance, improving the utilization of the protein in the diet. 
Table 3. Nitrogen balance of pigs and biological value on diets containing skim milk powder or CMC whey product as protein supplement.

\begin{tabular}{lccc}
\hline & \multicolumn{3}{c}{ Protein supplement } \\
\cline { 2 - 4 } & $\begin{array}{c}\text { Skim milk powder } \\
100 \%\end{array}$ & $\begin{array}{r}\text { Skim milk } 50 \% \\
\text { CMC whey } 50 \%\end{array}$ & $\begin{array}{r}\text { CMC whey } \\
\text { product } 100 \%\end{array}$ \\
\hline Nitrogen & & & \\
Intake, g/d & 48.7 & 47.8 & 48.8 \\
Faeces, g/d & 8.3 & 8.2 & 8.6 \\
Absorbed, g/d & 40.4 & 39.6 & 40.2 \\
Urine, g/d & 13.7 & 13.4 & 12.1 \\
Retained, g/d & 26.7 & 26.2 & 57.6 \\
$\%$ of intake & 54.8 & 54.8 & 69.9 \\
\% of absorbed & 66.1 & 66.2 & 82.1 \\
Biological value & 78.4 & 78.8 & \\
\hline
\end{tabular}

Table 4. Blood composition in pigs fed diets with and without the CMC whey product.

\begin{tabular}{|c|c|c|c|c|c|c|}
\hline & \multicolumn{6}{|c|}{ Protein supplement } \\
\hline & \multicolumn{2}{|c|}{ Skim milk $100 \%$} & \multicolumn{2}{|c|}{$\begin{array}{l}\text { Skim milk } 50 \% \\
\text { CMC whey } 50 \%\end{array}$} & \multicolumn{2}{|c|}{ CMC whey $100 \%$} \\
\hline & $\overline{\mathbf{x}}$ & SD & $\overline{\mathbf{x}}$ & $\mathrm{SD}$ & $\overline{\mathbf{x}}$ & SD \\
\hline PCV, \% & 37.9 & 4.4 & 39.5 & 3.2 & 39.9 & 5.3 \\
\hline $\mathrm{Hb}, \mathrm{g} / \mathrm{l}$ & 124.8 & 10.7 & 127.2 & 12.6 & 128.2 & 16.3 \\
\hline Plasma glucose, $\mathrm{mmol} / \mathrm{l}$ & 5.7 & 0.5 & 5.3 & 0.2 & 5.5 & 0.5 \\
\hline Urea, $\mathrm{mmol} / \mathrm{l}$ & 3.1 & 0.5 & 2.4 & 0.6 & 2.1 & 0.9 \\
\hline Total protein, g/l & 66 & 4 & 66 & 4 & 66 & 4 \\
\hline Albumin, $\mathrm{g} / \mathrm{l}$ & 43 & 4 & 42 & 3 & 43 & 4 \\
\hline Creatinine, $\mu \mathrm{mol} / 1$ & 173 & 19 & 172 & 17 & 161 & 13 \\
\hline Cholesterol, mmol/1 & 2.9 & 0.1 & 3.0 & 0.2 & 2.9 & 0.3 \\
\hline Total bilirubin, $\mu \mathrm{mol} / 1$ & 1.4 & 0.4 & 1.1 & 0.2 & 1.3 & 0.5 \\
\hline $\mathrm{P}, \mathrm{mmol} / \mathrm{l}$ & 2.7 & 0.1 & 2.7 & 0.1 & 2.7 & 0.1 \\
\hline $\mathrm{Ca}, \mathrm{mmol} / \mathrm{l}$ & 3.0 & 0.2 & 2.9 & 0.1 & 3.0 & 0.3 \\
\hline $\mathrm{Mg}, \mathrm{mmol}$ & 0.90 & 0.03 & 0.83 & 0.05 & 0.79 & 0.07 \\
\hline $\mathrm{AP}, \mu \mathrm{kat} / \mathrm{l}$ & 12.6 & 2.6 & 12.7 & 2.0 & 12.9 & 1.9 \\
\hline ALAT, $\mu \mathrm{kat} / 1$ & 0.54 & 0.10 & 0.52 & 0.06 & 0.45 & 0.08 \\
\hline ASAT, $\mu \mathrm{kat} / \mathrm{l}$ & 0.62 & 0.19 & 0.64 & 0.10 & 0.62 & 0.22 \\
\hline $\mathrm{CK}, \mu \mathrm{kat} / \mathrm{l}$ & 30.0 & 3.6 & 25.3 & 13.6 & 26.1 & 10.9 \\
\hline$\gamma$-GT, $\mu$ kat $/ 1$ & 0.77 & 0.85 & 0.54 & 0.29 & 0.72 & 0.55 \\
\hline $\mathrm{LDH}, \mu \mathrm{kat} / \mathrm{l}$ & 25.4 & 6.4 & 24.7 & 5.6 & 26.2 & 9.9 \\
\hline
\end{tabular}

The data on the composition of the blood in pigs fed on the CMC whey product or skim milk are presented in Table 4 . The differences between the pigs on the various diets are very small and none was statistically significant $(\mathrm{P}>0.05)$. The values correspond fairly closely to those obtained in other experiments (NÄSI et al. 1978, NÄSI and TANHUANPÄÄ 1981) and all lie within the normal range (SCHMIDT 1979). Blood urea was a little lower on the CMC whey diet, which EGGUM (1970) considers to be a sign of improved 
protein utilization. The plasma $\mathrm{Mg}$ content can also be seen to be lower, which is in line with lower $\mathrm{Mg}$ content in CMC whey.

When used instead of skim milk to supplement a barley-based diet for pigs, the CMC whey product gave as good or slightly better values for protein retention and utilization. Judging from the blood analysis, CMC did not have any harmful effects on the metabolism or health of the pigs. These findings indicate that the $\mathrm{CMC}$ whey product is very suitable as a protein supplement for pigs. Due to its low $\mathrm{pH} 3.2$ the product can also be stored for two-three weeks without deteriorating. Some technical questions regarding the production of CMC whey remain to be resolved and the economic aspects must also be considered.

\section{REFERENCES}

ALAVIUHKOLA, T., HARJU, M., HEIKONEN, M. \& KREULA, M. 1980. The effects of the hydrolysis of lactose in whey on its value in the feeding of growing-finishing pigs. Acta Agric. Scand. 30: 13-16.

ANON. 1963. Specifications for the identity and purity of food additives and their toxilogical evaluation: emulsifiers, stabilizers, bleaching and maturing agents. FAO Nutr. Meet. Rep. Ser. 35: 87-94.

ANON. 1964. FIL-IDF 28: 1964. International standard. Determination of the lactose content of milk.

BARBER, R. S., BRAUDE, R., MITCHELL, K. G. \& PITTMAN, R. J. 1978. The nutritive value of liquid whey, either sour or sweet, when given in restricted amounts to the growing pig. Anim. Feed Sci. Technol. 3: 163-177.

DIGGS, B. G., BECKER, D. E., JENSEN, A. H. \& NORTON, H. W. 1965. Energy value of various feeds for the young pig. J Anim. Sci. 24: 555.

EGGUM, B. O. 1970. Blood urea measurement as a technique for assessing protein quality. Br. J. Nutr. 24: 983-988.

HANRAHAN, T. J. 1971. Whey solids in the diet for growing-finishing pigs I. Dried whey as a feed for pigs. Ir. J. Agric. Res. 10: 1-7.

HIDALGO, J. \& HANSEN, P. M. T. 1971. Selective precipitation of whey proteins writh carboxy methyl cellulose. J. Dairy Sci 54: 1270-1274.

MITCHELL, G. 1978. Feeding skim and whey. Pig Farming 27 (11): 79-81.

NÄSI, M. 1982. Nutritive value of Eurolysine bacterial protein and Pekilo protein for growing pigs. J. Scient. Agric. Soc. Finl. 54: 263-269.

— , SALONIEMI, H. \& KALLELA, K. 1978. Hematological and blood chemical data of pigs fed various amounts of mink manure. Acta Vet. Scand. 19: 84-92.

- , TANHUANPÄÄ, E. 1981. The effects of sugar alcohols on metabolism of growing pigs. Acta Vet. Scand. 22: 344-354.

SCHMIDT, M. 1979. Laboratory testing in veterinary medicine. Diagnosis and clinical monitoring. Boehringer Mannheim GmbH. 130 p.

ZIEGELMAYER, W., COLUMBUS, A., KLAUSCH, W. \& WIESKE, R. 1951. Einfluss der Carboxymethylcellulose auf die Verdauung nach Untersuchungen an Ratte, Mensch und Kaninchen. Arch Tierernähr. 2: 33-52.

Ms received December 3. 1982. 


\section{Karboksimetyyliselluloosalla (CMC) saostettu hera lihasikojen val- kuaislähteenä}

\section{Matti Näsi ja Matti Ikonen}

Helsingin yliopisto, kotieläintieteen laitos, 00710 Helsinki 71

\section{Matti Antila}

Helsingin yliopisto, maitotaloustieteen laitos, 00710 Helsinki 71

Sulavuus- ja tasekokeessa tutkittiin karboksimetyyliselluloosalla saostetun heraproteiinin rehuarvoa ja valkuaisen hyväksikäyttöä lihasioilla. CMC-heran raakavalkuaispitoisuus oli 39.6 \% kuiva-aineesta. Välttämättömiä aminohappoja CMC-hera sisälsi runsaasti. Lysiiniä oli 10.3, kystiiniä 2.9, metioniinia 2.1 ja treoniiniä $5.6 \mathrm{~g} / 100 \mathrm{~g}$ raakavalkuaista. Typettömien uuteaineiden sulavuus oli merkitsevästi $(\mathrm{P}<0.05)$ alempi $\mathrm{CMC}$-heradieetillä kuin kurrijauhodieetillä. CMC:stä erittyi sonnassa $59.0 \%$. Valkuaisen hyväksikäyttö oli CMC heradieetillä tehokasta, $69.9 \%$ imeytyneestä raakaproteiinista pidättyi sian elimistöön. Verianalyysien perusteella CMC heralla ei ollut mitään haitallisia vaikutuksia sikojen aineenvaihduntaan tai terveyteen. CMC hera osoittautui hyväksi valkuaislähteeksi lihasikojen ruokinnassa erityisesti korkean lysiinipitoisuuden takia. 